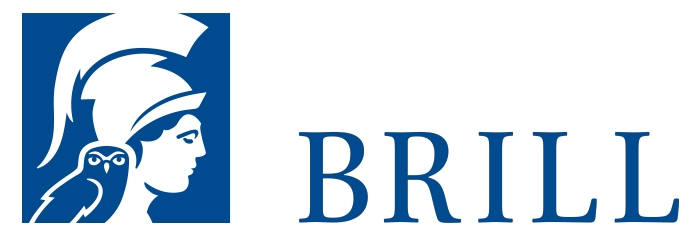

\title{
The Horizon of Modernity
}

Subjectivity and Social Structure in New Confucian Philosophy

Author: Ady Van den Stock

The Horizon of Modernity provides an extensive account of New Confucian philosophy that cuts through the boundaries between history and thought. This study explores Mou Zongsan's and Tang Junyi's critical confrontation with Marxism and Communism in relation to their engagement with Western thinkers such as Kant and Hegel. The author analyzes central conceptual aporias in the works of Mou, Tang, as well as Xiong Shili in the context of the revival of Confucianism in contemporary China and the emergence of the discipline of philosophy in twentieth-century Chinese intellectual history. This book casts new light on the nexus between the categories of subjectivity and social structure and the relation between philosophy, modern temporality, and the structural conditions of the modern world.

Readership

Scholars and students interested New Confucianism, modern Chinese intellectual history, contemporary Chinese and comparative philosophy, and anyone concerned with the problem of modernity in general.

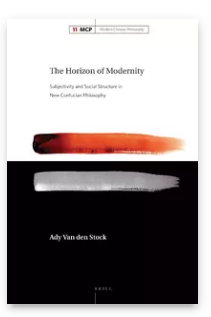

Pages: viii, 404 pp.

Language: English

Subjects: China, Asian Studies,

Asian

Philosophy,

Philosophy,

Intellectual

History, History, 19th \& 2oth

Century

Philosophy,

Philosophy,

Social \&

Political

Philosophy,

Philosophy

Publisher: Brill

Series:

Modern Chinese

Philosophy,

Volume: 11

E-Book (PDF)

Released online:

1o Jun 2016

ISBN: 978-90-

04-30110-8

List price

USD $\$ 192.00$

Hardback 
Publication date:

23 Jun 2016

Ady Van den Stock obtained a Ph.D in Oriental Languages and Cultures at Ghent University (Belgium) in 2015. He researches modern Chinese intellectual history and the reinvention of traditional thought in the context of the historical transformations of modern society.

For more information see brill.com

Order information: Order online at brill.com +44330 333 oo49 | customerservices@brill.com Submission information: brill.com/authors

Titles published by Brill $\mid$ Fink, Brill $\mid$ mentis or Brill | Schöningh: +49(o)71 5413279216 | brill@brocom.de

ISBN: $978-90-$

04-30109-2

List price

USD \$192.00 